\title{
Here Versus There: Creating British Sexual Politics Elsewhere
}

\author{
Kay Lalor $^{1}$ D $\cdot$ Katherine Browne ${ }^{2}$
}

Published online: 5 September 2018

(c) The Author(s) 2018

\begin{abstract}
This reflection draws upon two recent 'moments' in British sexuality politics - a series of Parliamentary debates on Global LGBT rights and Brighton Pride's campaign to 'Highlight Global LGBT Communities'. It contrasts these two moments in order to demonstrate how, at a time when LGBT rights have ostensibly been 'won' in the UK, there is an increasing tendency to shift focus to the persecution of SOGI minorities elsewhere in the world. This shift in focus sets up a binary of here versus there that is politically persuasive but ultimately limited and limiting. By reflecting on the way that this growing trend of creating sexual politics elsewhere occurs in two very different locations in British politics and activism, we seek to begin a conversation about the relational affects of placing sexual politics 'elsewhere'.
\end{abstract}

Keywords Sexual politics · Pride · Global LGBT rights

\section{Introduction}

This reflection is part of an ongoing interdisciplinary conversation about what happens when LGBTQI (Lesbian, Gay, Bisexual, Trans, Queer and Intersex) rights have ostensibly been "won". It is a response to, and an engagement with, recent developments in UK LGBTQI politics, as we move towards the end of Pride season after a year in which there has been considerable National Parliamentary discussion of 'Global LGBT rights'. With the advent of sexual and gender equality legislation, and particularly same sex marriage, in some places, some queer bodies are viewed as worthy of state protection (Duggan 2002; Puar 2013, although see Brown 2012 for a critique of the universalising of these critiques). We are concerned with what

Kay Lalor

k.lalor@mmu.ac.uk

1 Faculty of Business and Law, Manchester Metropolitan University, Lower Ormond St, Manchester M15 6BH, UK

2 Department of Geography, Maynooth University, National University of Ireland Maynooth, Maynooth, Ireland 
the (British) state and political actors $d o$ once these protections come into force and more specifically, where do they locate politics when "here" is seen as "sorted"? Our observation is that a shift of focus occurs in which "elsewhere" is foregrounded as a space of violence and a space of politics and activism, and that these politics will be satisfied when they have laws "like us".

Much has been said about homonationalism and the creation of others who need to be "saved" (Haritaworn 2015; Puar 2007; Rao 2010). In this reflection, we add to these considerations, drawing attention to the creation of UK based politics that rest upon a comparison of "here" and "there". We use two particular instances to trace this dynamic-Parliamentary debates on Global LGBT rights ${ }^{1}$ over the past year, and at Brighton Pride from 2014 onwards. In so doing, we do not seek to set up a binary between state practice and mass protest. Instead we wish to draw attention to the extent to which the tendency to contrast victories won at home with violence abroad has become a mainstay of British LGBTQI politics-it is found in multiple forms at multiple different levels of political action. The use of this comparative framework is limiting: it exports problems and violence "elsewhere" and creates specific narratives of "here". It is a colonising move, that carefully repositions violence in a way that recreates geopolitical hierarchies and associates the passage of equalities legislation with "progress" (Weber 2016), in contrast to backward others (Kulpa and Mizielinska 2011; Kulpa 2014; Browne et al. 2015; Rao 2014). The narrative sets out particular pre-ordained paths to "victory" based on Global North trajectories and imaginaries of social progress, as well as relationships and kinships. Focusing on British politics and activism, this reflection seeks to augment conversations about the relational affects of placing sexual politics "elsewhere".

\section{Global LGBT Rights: Elsewhere as Violent}

The Equality Act 2010 enshrined protections for Sexual Orientation and Gender Identities (SOGI) into British law, creating "world leading" legal framework and placing Britain at the top of "rainbow" hierarchies produced to evaluate "homophobic states" (Browne et al. 2015). Since 2015, the UK Parliament has had a dedicated All Party Parliamentary Group (APPG) on Global LGBT Rights that seeks to "advance LGBT rights around the world" by providing "a forum for parliamentarians and organisations across the public, private and third sectors to work together to champion LGBT rights and push back against abuse and discrimination" (APPG 2018a). The APPG has secured two House of Commons debates on LGBT rights in the past year and lobbied hard to place LGBT rights on the agenda at the $2018 \mathrm{Com}$ monwealth Heads of Government Meeting (CHOGM), hosted by the UK (APPG 2018b).

\footnotetext{
1 We use LGBT rights and activism to reflect the more frequent use of LGBT in British law and politics. In using this terminology we recognise its potential exclusion of intersex, queer, asexual and other identities and actors. This potential for exclusion is reflective of wider tensions within LGBTQI politics.
} 
Britain's imperial history is heavily implicated in its current approach to SOGI. Indeed, at CHOGM 2018, Theresa May expressed her "deep regret" for the British Empire's role in perpetuating homophobic legislation that remains in force in many countries (Crerar 2018). Yet this deep regret for past sins remains part of a carefully controlled political rhetoric with respect to the UK's current role in global LGBT(QI) politics. As Lloyd Russell-Moyle MP noted in one of the APPG's debates:

We must be clear that we have a moral duty to speak out for human rights... Why are there laws against LGBT people in so many countries? Why is there section 377 of India's penal code? Why are there sections 76 and 77 of Jamaica's Offences Against the Person Act 1861?... Why is there section 377A of Singapore's penal code... Why? Because, of course, those laws were imposed by British colonial rule and imperialism. ${ }^{2}$

Here, Britain's past sins produce a duty to "speak out" in the present. Underpinning this is the assumption that as a nation that has "progressed" on LGBT rights, the UK is and should be a "world leader" on the issue. As the Minister for Women, Victoria Atkins MP, noted in the APPG's debate to mark IDAHOT (International Day Against Homophobia, Transphobia and Biphobia) in May 2018:

From the equalisation of the age of consent to the introduction of same-sex marriage, successive [UK] Governments have made significant progress in advancing equality for LGBT people, who now enjoy the right to marry, to start a family and to change their legal gender to match their identity. As a result, the UK is recognised globally as a world leader on LGBT rights. ${ }^{3}$

This creates a narrow, rights-dependent and teleological framework of progress, usually beginning with decriminalisation, progressing to the passage of equalities legislation, culminating in equal marriage. And while LGBT rights are one possible framework for pursuing SOGI justice, they can also be limiting, regulatory and exclusionary (e.g. Franke 2012; Kapur 2015; Oswin 2008; Puar 2013; Richardson 2004; Robertson 2012; Sears 2005; Spade 2013; Stychin 2003). However, our interest is not just in the limits of law but in the act of displacement that this legalistic focus performs. In the debates cited above, the worst forms of violence against SOGI minorities are relocated away from the UK: either to the past actions of Empire, or to elsewhere in the world.

This displacement relies on carefully drawn spatial and temporal divides. The horrors of empire are safely relocated to another time. Present violence is removed to non-UK locations-particularly to the Global South. This spatial and temporal displacement of violence assumes that the progressive movement away from violence can be primarily facilitated by law (Rao 2010; Weber 2016). It does not entirely obscure ongoing violence at home, but it can reduce the estimation of the seriousness of this violence by assuming that the structural/legal solutions in place

\footnotetext{
2 HC Deb 26 October 2017, vol 630, col 539.

3 HC Deb 17 May 2018, vol 641, col 533.
} 
are sufficient and simply require further or better implementation. This framing ties LGBTQI politics to the scale of the nation state (Bacchetta 2002; Shah 2015), which becomes both the originator of violence "elsewhere" and the body most able to exercise power to end violence and protect LGBTQI subjects (Franke 2012).

These spatial displacements and legal assumptions have profound political effects. "Elsewhere" is (re)produced as the space of legal and political violence that has yet to progress. This dynamic is not limited to legal and policy-based contexts: as we discuss below, certain UK based Pride organisations have also sought to shore up support by seeking politics that focuses on what is yet to be achieved "elsewhere".

\section{Politics of Pride: Elsewhere is Political}

Pride has long been a controversial site of politics that can be associated with pleasure and partying (Browne 2007). Initially this was related to how heteronormative streets in the Global North were "queered" offering spatio-temporal respite to everyday, ubiquitous and seemingly "natural" heteronormativities (Bell and Valentine 1995; Bell et al. 1994), creating displacements that challenge heteronormative streets (Brickell 2004; Johnson 2005, 2007).

However, with changing legislation and cultural associations, Prides-particularly in the Global North-have been criticised for their commercialisations and assimilations, including by alternative and protest events that question the position of Prides as parties, and as assimilationist, rather than political sites (Johnson 2007; Brown 2007).

Of course, all Pride events are different, created in place and in relation to local as well as national and transnational politics (Browne and Bakshi 2013). Thus, generalisations regarding whether Pride is, or is not, political, and what that politics entails, are inherently geographical. However, there is another layer of geography that needs to be considered here. Whilst Binnie and Kleese (2012) have examined the transnational connections of LGBT activists in the late twentieth century, there are new globalising tendencies within UK Pride events that need critical attention.

Here we use Brighton Pride to highlight some of the politicisations of Pride that seek to counter the accusation that Pride is "no longer political". Brighton Pride is located in a city that sees itself as the "gay capital of the UK", which itself is generative of specific political possibilities (Browne and Bakshi 2013). The accusation of a Brighton Pride that is no longer political-particularly after introducing charging, fencing, and a main stage with large pop-based headline acts, such as Britney Spears, as well as its emphasis on "coming together to celebrate every aspect of our city, regardless of sexuality, race, gender, age or ability" (Brighton Pride 2018a) — has been met with donations to a "Rainbow fund" (for local LGBT communities, distributed through a self-appointed board) in the form of an extra $£ 1$ on ticket entry, a rebranding of the parade as a "community parade" and also a more explicit discourse on the location of politics elsewhere. This can be seen initially at the 2014 Brighton Pride parade and within ongoing discourses that focused on "Pride Campaigning to Highlight Global LGBT Communities". This created the 
place of Brighton Pride as not only a significant UK event (measured by size, around 300,000-400,000 attendees at the Parade), but also as a globally significant "leader":

As one of the UK's biggest Pride festivals, Brighton Pride leads the way in campaigning for the rights of our global LGBTQI community...Campaigning to highlight global LGBT communities and community fundraising is at the cornerstone of everything Pride represents. (Brighton Pride 2018b)

Moving between the local and national, Brighton Pride's "cornerstone" and "everything it represents" highlights global LGBTQI communities and (local) community fundraising. Pride as a "festival" becomes political through campaigning, rather than through riots and protest. This campaigning is located "elsewhere", in the "rights of our Global LGBTQI communities". Whilst LGBTQI communities in Brighton need funding, global LGBTQI people need politics, campaigning and activism:

By highlighting the lives of LGBTQI communities across the globe Brighton Pride asks us to look beyond our own backyard and engage with those LGBTQI people living in countries who criminalise or persecute them purely because of their gender or sexuality (Brighton Pride 2018b).

The targeting of this criminalisation and persecution immediately turns the focus to the Global South, and associates diverse places, with long complex histories, cultures and contemporary situations with violence, danger and "horror":

The Egyptian government's recent crackdown on the freedoms enjoyed by gay men with increasing arrests and prosecutions, the horrific pictures allegedly showing two gay men being thrown to their deaths from the top of a tower released by the self proclaimed Islamic State (ISIS) earlier this month (Ibid).

Placing Egypt and Isis in close proximity links death with "poor" and Muslim nations. This is in contrast to the UK who need to "stand beside those in other countries"

Brighton Pride 2015 Freedom To Live campaign, started in 2013, will show that as a LGBTQI community here in the UK we can stand beside those in other countries and campaign for the freedom to live. The 2015 Brighton Pride Community Parade will highlight the 78 countries where it is illegal to be homosexual or engage in homosexual conduct by once again including 78 placards representing those countries on the parade. Amongst the Pride celebrations, we will remember, we will campaign and we will connect to the many LGBTQI communities across the globe fighting for the freedom to live. Brighton Pride, proud to be a voice for others, proud to be a Pride with purpose.

\footnotetext{
4 Note the USA was also named but not in relation to homophobic hate crime, but instead slow legislative processes in the Obama era, and is not included in the 78 countries.
} 
Make your voice heard in the fight for global LGBTQI equality and volunteer to hold one of the 78 countries Freedom To Live placards on the Brighton Pride Community Parade (Brighton Pride 2018b).

The discourse here is clear. Brighton Pride is 'a voice for others'-not seeking to give voice and empower, but instead be a voice, the voice. As one of the "biggest Pride festivals in the UK" it seeks to represent others, creating "Pride with a purpose", which manifests the campaigning promise, without implicating the Pride organisation, any of its sponsors or state supporters. The LGBT person can volunteer to hold a placard, to be part of this politics, but it is not the voices of other places that are heard, it is "your voice", which comes to matter. There is little recognition of voices that might be critical, political but not encompassed in "Pride with a purpose". Indeed, in Paul Kemp's (Director of Brighton Pride) terms, Brighton Pride is a:

[U]nique yearly opportunity to put the spotlight on the plight of those LGBT communities around the world who do not have the same freedoms as are enjoyed in the United Kingdom. ... use the media spotlight to focus on our LGBT brothers and sisters living in countries such as Oman, Somalia, Dominica, India, Tonga, Russia, Egypt, and Iraq, who do not enjoy the freedoms that we can so often take for granted. (Kemp 2014)

The UK becomes the place of freedoms, presumably for all LGBTQI people, in contrast with "brothers and sisters" in other dangerous places. Thus, in places such as Brighton, the need to claim and proclaim a politics has meant specific moves that connect "here" and "there". This produces an othering effect by proclaiming the "dangers" of other places, in contrast to "here", where people are asked to stand "beside" in order to campaign for other nations. These places are seen as having "real" problems that make LGBTQI lives much worse than "here". Thus, whilst we might contest the "loss" of politics of (Brighton) Pride, organisational reactions to this loss have instead drawn on specific ideals of "here", where funding might be needed through the Rainbow fund, but politics is unnecessary as "freedom" prevails. This is compared to the elsewhere of "other places", where politics, campaigning and remembering are required and create political pride parties here.

\section{Beyond Here and There? "Non-comparative" Transnationalisms}

The comparative framework that juxtaposes "here" and "there" has not emerged in a vacuum, nor are the two cases that we present in this reflection the only instances of its operation. Even among some NGOs and social movement organisations working on LGBTQI issues, that demonstrate an awareness of the "complex challenges" (Kaleidoscope International Trust 2018) of transnational LGBT activism, language that continues to rest upon a framework of "here" and "there" persists (see for example Kaleidoscope International Trust 2018; Waites 2017; ILGA 2017). The points presented in this reflection could be further developed through other cases that explore the extent to which comparative framings are implicitly operationalised in 
LGBTQI rights, the complexities of these framings, and the connections between the different forums in which these framings hold sway. In this reflection, we have highlighted and responded to House of Commons debates and Brighton Pride, seeking to begin explorations of political discourse within the UK legislature and at a mass event that presents the "public face" of LGBT politics. There is a great deal of scope for further analysis of how "here" and "there" are created, including the complexities of who is "here" and who are located "there", even when they are here.

The danger that we point to in this short piece is therefore one in which a simplified narrative of "here versus there" is repeated and reconstructed within different hegemonic forums of British LGBTQI politics. This narrative is inherently hierarchical; it renders some forms of violence particularly visible while marginalising others. It imagines the space of "here" and "there" as undifferentiated and homogenous. And it teleologises the path to LGBTQI/SOGI justice along a single-legally informed-framework.

Moreover, just as Haritaworn (2015) has pointed to the danger of "invented traditions" of "women-and-gay-friendliness" that animate national imaginaries, we seek to problematise the invented or imagined comparisons and connections that underlie the different forms of LGBTQI politics that we explore here. Multiple times in political discourse, a celebration of British progress was followed by a call to remember those who are not fortunate enough to live in states that have passed protective legislation. Similarly, the celebration of one of the "Biggest UK Prides" is embedded in the imperative to campaign for other people, in other places. And while it is important to be aware of injustice, wherever it occurs, the rhetorical repetition of "here = progressive and legally regulated"/"there = violent and backwards" is telling. It is inherently linked to a politics of knowledge production that maintains a dependency and discursive link between the progress here and backwardness there. Here and there become mutually co-constitutive and British leadership, activism and progress become interdependent with the existence of far-off suffering. From the politics of Pride to the halls of political power, the recognition of violence is carefully mediated through an already existing framework within which the terms of debate, the parameters by which we measure success, failure, violence or safety are maintained and set.

This is a problem of knowledge production as well as political action and organising. The power dynamics of this knowledge production are stark-Haritaworn $(2015,26)$ has highlighted the risks inherent in speaking and writing queer of colour scholarship. And in a different context, Nyanzi (2015) and Macharia (2016) have both written about the misunderstandings, caricatures and miscommunications that are liable to occur when queer African knowledge and scholarship is excluded from knowledge production about queerness in Africa. As (British and Irish) scholars, we too are implicated in these forms of knowledge production that lead to the comparative repetition of "here vs there"-as we seek to influence policymakers we must wrestle with how much we must speak their "language". We are subject to academic and publication pressures that lend themselves to following well-worn comparative methodological paths and we benefit from the "progressive" equality legislation that distinguishes itself through comparison with violence elsewhere. The here/there narratives are pervasive and 
convincing because they draw on the narrative of winning. They say more about the British context than they do about the places to which they are compared. More activist and academic work is needed to understand, critique and address these narratives as they move through and reconstruct Britain and Britishness in and through sexual and gender politics.

Acknowledgements We are grateful to the Feminist Legal Studies reflections editors for their comments and support in writing this piece. This reflection was supported by an ESRC Grant ES/M000931/1 and a Leverhulme Early Career Fellowship ECF-2015-612.

\section{Compliance with Ethical Standards}

Conflict of interest The authors declare no potential conflicts of interest with respect to the research, authorship, and/or publication of this article.

Open Access This article is distributed under the terms of the Creative Commons Attribution 4.0 International License (http://creativecommons.org/licenses/by/4.0/), which permits unrestricted use, distribution, and reproduction in any medium, provided you give appropriate credit to the original author(s) and the source, provide a link to the Creative Commons license, and indicate if changes were made.

\section{References}

APPG. 2018a. All Party Parliamentary Group on Global LGBT Rights 'About Us' https://www.appglgbt. org/about. Accessed 4 July 2018.

APPG. 2018b. All Party Parliamentary Group on Global LGBT Rights. https://www.appglgbt.org. Accessed 4 July 2018.

Bacchetta, Paola. 2002. Rescaling Transnational "Queerdom": Lesbian and "Lesbian" Identitary-Positionalities in Delhi in the 1980s. Antipode 34: 947-973.

Bell, David, and Gill Valentine. 1995. Mapping Desire: Geographies of Sexualities. London: Routledge.

Bell, David, Jon Binnie, Julia Cream, and Gill Valentine. 1994. All Hyped Up and No Place to Go. Gender, Place and Culture 1: 31-47.

Binnie, Jon, and Christian Kleese. 2012. The Politics of Age, Temporality and Intergenerationality in Transnational Lesbian, Gay, Bisexual, Transgender and Queer Activist Networks. Sociology 66(1): 191-206.

Brickell, Chris. 2004. Heroes and Invaders: Gay and Lesbian Pride Parades and the Public/Private Distinction in New Zealand Media Accounts. Gender, Place and Culture 7: 163-178.

Brighton Pride. 2018a. Community. https://www.brighton-pride.org/community/. Accessed 28 June 2018.

Brighton Pride. 2018b. Pride Campaigning to Highlight Global LGBT Communities. https://www.brigh ton-pride.org/pride-campaigning-to-highlight-global-lgbt-communities-2/. Accessed 28 June 2018.

Brown, Gavin. 2007. Mutinous Eruptions: Autonomous Spaces of Radical Queer Activism. Environment and Planning A 39: 2685-2698.

Brown, Gavin. 2012. Homonormativity: A Metropolitan Concept that Denigrates “Ordinary” Gay Lives. Journal of Homosexuality 59: 1065-1072.

Browne, Katherine, and Leela Bakshi. 2013. Ordinary in Brighton: LGBT, Activisms and the City: Lesbian, Gay, Bisexual and Trans Lives and Activisms. Farnham: Ashgate.

Browne, Katherine, Niharika Banerjea, Leela Bakshi and Nicholas McGlynn. 2015. Intervention - GayFriendly or Homophobic? The Absence and Problems of Global Standards. AntipodeFoundation. Org. https://antipodefoundation.org/. Accessed 31 Aug 2018.

Browne, Katherine. 2007. A Party with politics? (Re)making LGBTQ Pride Spaces in Dublin and Brighton. Social and Cultural Geography 8: 63-87.

Crerar, Pippa. 2018. Theresa May Says She Deeply Regrets Britain's Legacy of Anti-gay Laws. The Guardian, 17 April. https://www.theguardian.com/world/2018/apr/17/theresa-may-deeply-regre 
ts-britain-legacy-anti-gay-laws-commonwealth-nations-urged-overhaul-legislation. Accessed 31 Aug 2018.

Duggan, Lisa. 2002. The New Homonormativity: The Sexual Politics of Neoliberalism. In Materializing Democracy: Toward a Revitalized Cultural Politics, ed. R. Castronovo and D.D. Nelson, 175-194. Durham: Duke University Press.

Franke, Katherine. 2012. Dating the State: The Moral Hazards of Winning Gay Rights. Columbia Human Rights Law Review 44: 1-46.

Haritaworn, Jin. 2015. Queer Lovers and Hateful Others: Regenerating Violent Times and Places. London: Pluto Press.

ILGA. 2017. Maps-Sexual Orientation Laws. https://ilga.org/maps-sexual-orientation-laws Accessed 15 Aug 2018.

Johnston, Lynda. 2005. Queering Tourism: Paradoxical Performances at Gay Pride Parades. London: Routledge.

Johnston, Lynda. 2007. Mobilizing Pride/Shame: Lesbians, Tourism and Parades. Social and Cultural Geography 8: 29-45.

Kaleidoscope International Trust. 2018. About Us. https://kaleidoscopetrust.com/about-us/. Accessed 15 Aug 2018.

Kapur, Ratna. 2015. Precarious Desires and Ungrievable Lives: Human Rights and Postcolonial Critiques of Legal Justice. London Review of International Law 3: 267-294.

Kemp, Paul. 2014. Pride: More than a Celebration. Brighton \& Hove Independent Thursday 26th June. https://www.brightonandhoveindependent.co.uk/news/pride-more-than-a-celebration-1-7720331. Accessed 28 June 2018.

Kulpa, Robert and Joanna Mizielinska. 2011. De-Centring Western Sexualities: Central and Eastern Europeans Perspectives. London: Routledge

Kulpa, Robert. 2014. Western Leveraged Pedagogy of Central and Eastern Europe: Discourses of Homophobia, Tolerance, and Nationhood. Gender, Place \& Culture 21: 431-448.

Macharia, Keguro. 2016. On Being Area Studied: A Litany of Complaint. GLQ: A Journal of Lesbian and Gay Studies 22(2): 183-189.

Nyanzi, Stella. 2015. Knowledge is Requisite Power: Making a Case for Queer African Scholarship. In Boldly Queer: African Perspectives on Same-Sex Sexuality and Gender Diversity, ed. Theo Sandfort, Fabeinne Simenel, Kevin Mwachiro, and Vasu Reddy. The Hague: HIVOS.

Oswin, Natalie. 2008. Critical Geographies and the Uses of Sexuality: Deconstructing Queer Space. Progress in Human Geography 32: 89-103.

Puar, Jasbir K. 2007. Terrorist Assemblages: Homonationalism in Queer Times. Durham: Duke University Press.

Puar, Jasbir K. 2013. Rethinking Homonationalism. International Journal of Middle East Studies 45: 336-339.

Richardson, Diane. 2004. Locating Sexualities: From Here to Normality. Sexualities 7: 391-411.

Robertson, Colin. 2012. Decolonising Sexual Citizenship: Who Will Effect Change in the South of the Commonwealth. London: Commonwealth Bureau.

Rao, Rahul. 2010. Third World Protest. Oxford: Oxford University Press.

Rao, Rahul. 2014. The Locations of Homophobia. London Review of International Law 2(2): 169-199.

Sears, Alan. 2005. Queer Anti-Capitalism: What's Left of Lesbian and Gay Liberation? Science \& Society 69: 92-112.

Shah, Svati P. 2015. Queering Critiques of Neoliberalism in India: Urbanism and Inequality in the Era of Transnational "LGBTQ" Rights. Antipode 47: 635-651.

Spade, Dean. 2013. Under the Cover of Gay Rights. New York University Review of Law \& Social Change 37: 79-100.

Stychin, Carl. 2003. Governing Sexuality: The Changing Politics of Citizenship and Law Reform. Oxford: Hart.

Waites, Matthew. 2017. LGBTI Organizations Navigating Imperial Contexts: The Kaleidoscope Trust, the Commonwealth and the Need for a Decolonizing, Intersectional Politics. The Sociological Review 65(4): 644-662.

Weber, Cynthia. 2016. Queer International Relations: Sovereignty, Sexuality and the Will to Knowledge. Oxford: Oxford University Press. 